\title{
An Energy Supply Chain from Large Scale Photovoltaic Power Generation from Asian Cities to End Users in Japan
}

\author{
Akira Nishimura1', Takaki Yasui ${ }^{1}$, Satoshi Kitagawa', Masafumi Hirota ${ }^{1}$, Eric $\mathrm{Hu}^{2}$ \\ ${ }^{1}$ Division of Mechanical Engineering, Graduate School of Engineering, Mie University, Tsu, Japan \\ ${ }^{2}$ School of Mechanical Engineering, the University of Adelaide, Adelaide, SA, Australia \\ Email: nisimura@mach.mie-u.ac.jp
}

How to cite this paper: Nishimura, A., Yasui, T., Kitagawa, S., Hirota, M. and Hu, E. (2017) An Energy Supply Chain from Large Scale Photovoltaic Power Generation from Asian Cities to End Users in Japan. Smart Grid and Renewable Energy, 8, 145162.

https://doi.org/10.4236/sgre.2017.85010

Received: April 24, 2017

Accepted: May 24, 2017

Published: May 27, 2017

Copyright $\odot 2017$ by authors and Scientific Research Publishing Inc. This work is licensed under the Creative Commons Attribution International License (CC BY 4.0).

http://creativecommons.org/licenses/by/4.0/

c) (i) Open Access

\begin{abstract}
This study proposes four possible energy supply chains from the megawatt class of photovoltaics (PV) installation in Kuala Lumpur, Kolkata, Beijing or Ulan Bator to end users in Tokyo Japan. In the proposed chains, the electricity generated from solar PV panels would be used to generate $\mathrm{H}_{2}$ through water electrolyzer. The $\mathrm{H}_{2}$ is then liquefied (or converted into organic hydride) and transported by tank truck for land as well as tanker for marine to Japan and finally supplied to fuel cells (FC) for power generation purpose. This study investigates the energy efficiencies of the proposed energy supply chain and the amount of $\mathrm{CO}_{2}$ emission in the transportation process from the four locations. As a result, it is found the largest amount of power could be generated in Ulan Batorthan in other cities with the same size of solar panel array, while it also emitted the largest amount of $\mathrm{CO}_{2}$ in the transportation process. The best energy efficiency is obtained in the case of Beijing. This study also revealed that the ratio of total energy consumption to calorific value of $\mathrm{H}_{2}$ after transportation in the case of $\mathrm{H}_{2}$ liquefaction is smaller than that in the case of organic hydride.
\end{abstract}

\section{Keywords}

Energy Supply Chain, Photovoltaics, $\mathrm{H}_{2}$ Produced by Water Electrolysis, Energy Transportation

\section{Introduction}

Fossil fuel reserves are limited and intensive burning of hydro-carbon based fuel sources is impacting on global climate. Renewable energy sources such as wind, solar photovoltaic (PV), solar thermal, geothermal, bio-energy are drawing at- 
tention as alternative environment-friendly energy sources [1]. However, the energy density of these renewable energy sources is low. Most of them are dependent on nature and have intermittent characteristics. Therefore, it is very important to develop proper strategies and technologies to integrate these renewable energy sources into the power system network in order to fulfill the energy demand [1].

It was proposed that photovoltaics or wind turbine would be installed oversea where a good solar radiation and wind condition are obtained and the power generated by photovoltaics and wind turbine are converted into $\mathrm{H}_{2}$ by water electrolysis using the generated power and transported to Japan [2] [3]. If large renewable energy is produced in high potential area and transported to Japan, the energy demand would be fulfilled well. Therefore, this study proposes the energy supply chain consisting of large scale photovoltaics installed in several Asian cites which have a better solar radiation than Japan, water electrolysis for $\mathrm{H}_{2}$ production and transportation by tank truck for land as well as tanker for marine. Since gases $\mathrm{H}_{2}$ at atmospheric pressure is not suitable for transportation and storage due to low energy density, this study assumes to transport $\mathrm{H}_{2}$ produced by water electrolysis to Japan by means of liquefied $\mathrm{H}_{2}$ or organic hydride.

Due to solar energy's intermittent nature, the typical energy storage system in associated with normal PV systems such as battery bank and hydrogen produced by water electrolysis produced by the power of PV system is well known. Since the gravimetric energy density and the possible storage time of $\mathrm{H}_{2}$ are superior to battery, capacitance and flywheel [4] [5] [6] [7], $\mathrm{H}_{2}$ is suitable for long storage and transportation. The combination system of $\mathrm{PV}$ and $\mathrm{H}_{2}$ produced by water electrolyzer using renewable energy sources have been studied numerically as well as experimentally [8]-[23]. Energy and exergy analysis [8] [9] [10], economic assessment [11] [12] [13] [14] [15], environmental assessment [16] [17] and dynamic control procedure in a short time [18] [19] [20] were reported. Though the storage characteristics of $\mathrm{H}_{2}$ produced by water electrolisys are investigated [21] [22], there are a few reports that investigate the transportation system of $\mathrm{H}_{2}$ produced by water electrolysis using the power generated by renewable energy sources [3] [23], which are only discussed about $\mathrm{CO}_{2}$ emission and more investigations are necessary from the viewpoint of energy assessment. In addition, there is no study considering the $\mathrm{H}_{2}$ produced by water electrolysis using the power generated by large scale photovoltaics.

In this paper, a desktop case study has been conducted on a proposed energy supply chain. The proposed energy supply chain consists of solar panels, water electrolyzer, $\mathrm{H}_{2}$ liquefaction process (or conversion process from $\mathrm{H}_{2}$ into organic hydride), transportation by tank truck for land as well as tanker for marine and fuel cell (FC). Photovoltaic power generation of megawatt class is assumed to be installed in Kuala Lumpur, Kolkata, Beijing and Ulan Bator. The power generation characteristics of PV system assumed to be installed in four Asian cities were evaluated using meteorological data of METPV-ASIA [24]. The $\mathrm{H}_{2}$ is produced by the water elecrolyzer with power generated by PV system. The $\mathrm{H}_{2}$ is 
assumed to be transported after liquefaction or conversion into organic hydride. To convey the $\mathrm{H}_{2}$ energy from each city in Asia to Tokyo in Japan, tank truck and tanker are considered for land and marine transportation, respectively. This study investigates the electricity generated by PV system assumed to be installed in four Asian cities and the amount of $\mathrm{H}_{2}$ produced by water electrolysis using the electricity generated by PV system. This study also investigates the energy efficiency of the proposed energy supply chain and the amount of $\mathrm{CO}_{2}$ emission in the transportation process.

\section{The Proposed Energy Supply Chains}

This study proposes four energy supply chains sourced from four Asian cities to end users in Tokyo Japan, with the following assumptions:

1) Megawatt class of PV array would be installed in Asian cities where solar resources are good, i.e., Kuala Lumpur (Latitude: $3.08^{\circ} \mathrm{N}$, Longitude: $101.42^{\circ} \mathrm{E}$ ), Kolkata (Latitude: $22.34^{\circ} \mathrm{N}$, Longitude: $88.22^{\circ} \mathrm{E}$ ), Beijing (Latitude: $39.54^{\circ} \mathrm{N}$, Longitude: $116.23^{\circ} \mathrm{E}$ ) and Ulan Bator (Latitude: $47.55^{\circ} \mathrm{N}$, Longitude: $\left.106.55^{\circ} \mathrm{E}\right) . \mathrm{H}_{2}$ is produced by water electrolyzer using the electricity generated by PV system.

2) $\mathrm{H}_{2}$ is liquefied or converted into organic hydride as a carrier.

3) Liquefied $\mathrm{H}_{2}$ or organic hydride is transported from Asian cities to the nearest seaport by tank truck.

4) Liquefied $\mathrm{H}_{2}$ or organic hydride is transported from the sea port to Tokyo, Japan by tanker. When transporting liquefied $\mathrm{H}_{2}$, the transportation loss due to the boil-off rate of tanker is counted for estimation of amount of $\mathrm{H}_{2}$ after transportation.

5) Liquefied $\mathrm{H}_{2}$ or organic hydride is vaporized or reconverted into $\mathrm{H}_{2}$ and $\mathrm{H}_{2}$ is used for FC system to generate the power, in Japan.

In this study, the process 5 is ignored in the assessment. Figure 1 shows the world map showing the location of each city to be assessed in this study.

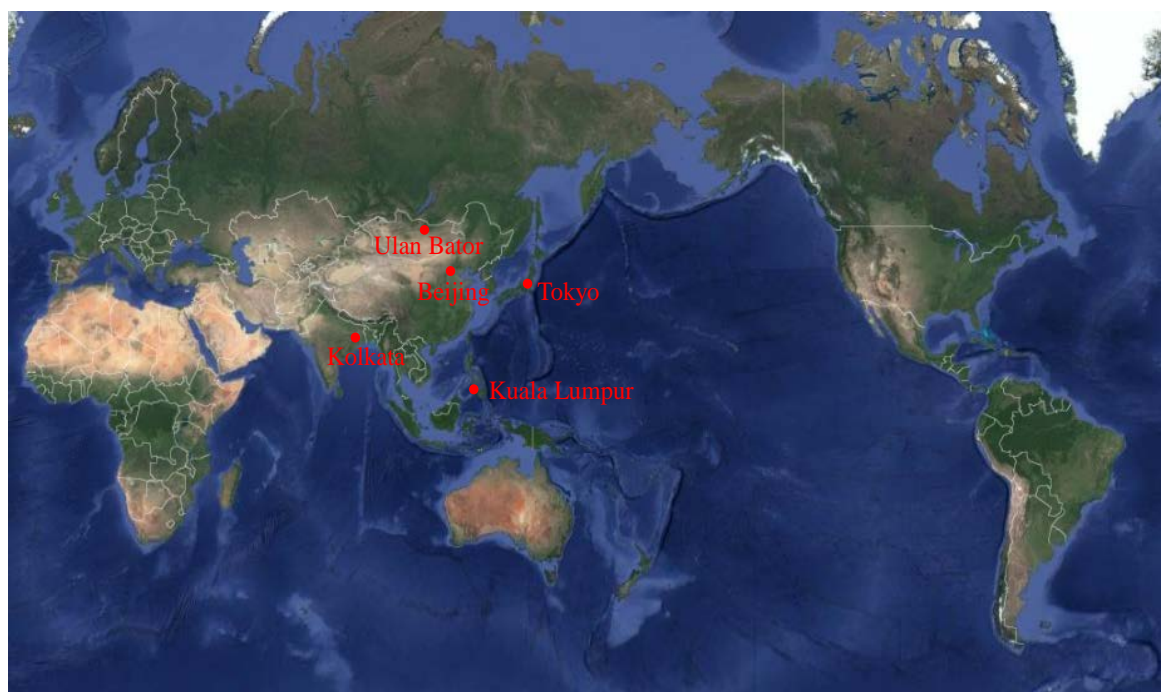

Figure 1. Location of the cities involved in this study. 


\section{Methodology of the Study}

\subsection{Estimation of Power Generation from the PV System}

The electricity generated by PV system is calculated by using the following equation [25]:

$$
E_{P V}=H \times K \times P / 1
$$

where $E_{P V}$ is hourly electricity generation from the PV system $(\mathrm{kWh}), H$ is amount of solar radiation $\left(\mathrm{kWh} / \mathrm{m}^{2}\right), K$ is power conversion factor $(-), P$ is system's peak capacity of PV $\left(\mathrm{kW}_{\mathrm{p}}\right), 1$ is solar peak radiation, i.e., $1 \mathrm{~kW} / \mathrm{m}^{2}$. The hourly solar radiation data of the reference [24] are used for calculating the hourly electric power of PV system.

In this study, the high performance PV P250a Plus produced by Panasonic whose module conversion efficiency and maximum power per module are 19.5\% and $250 \mathrm{~W}$ [26], respectively is adopted for PV system. The size of each PV module is $1580 \mathrm{~mm} \times 812 \mathrm{~mm} \times 35 \mathrm{~mm}$. To calculate $K$, the performance value of state-of-the-art commercial devise is used. $K$ is calculated by using the following equation [1]:

$$
K=K_{p} \times K_{m} \times K_{i}
$$

where $K_{p}$ is power conversion efficiency of power conditioner (-), $K_{m}$ is correction factor decided by module temperature $(-), K_{i}$ is power generation loss by interconnecting and dirty of module surface (-). In this study, $K_{p}$ and $K_{i}$ are set at 0.945 and 0.95 , respectively. $K_{p}$ is assumed by referring to the performance of commercial power conditioning device VBPC259B3 manufactured by Panasonic [27]. $K_{m}$ is calculated by the following equation [1]:

$$
K_{m}=1-\frac{\left(T_{m}-T_{s}\right) C}{100}
$$

where $T_{m}$ is PV module temperature (degree Celsius), $T_{s}$ is temperature under standard test condition ( $=25$ degree Celsius) (degree Celsius), $C$ is temperature correction factor which is 0.35 [28] (\%/degree Celsius). The temperature characteristics of PV module which is adopted for this study are referred. $T_{m}$ is calculated by using the following equation [29]:

$$
T_{m}=T_{a}+\left(\frac{46}{0.41 U_{m}^{0.8}+2}\right) H-2
$$

where $T_{a}$ is ambient air temperature (degree Celsius), $U_{m}$ is wind velocity over module of $\mathrm{PV}(\mathrm{m} / \mathrm{s})$. In this equation, the convection heat transfer by wind around the PV module is considered.

The meteorological data, such as solar radiation, the ambient air temperature, and wind velocity of the four Asian cities were from the data base of METPVASIA from 1999 to 2005 [24].

Table 1 and Figure 2 show monthly and annual mean temperature [30], and monthly precipitation [31] for the four Asian cities, respectively. These data are used for estimation of electricity generated by PV system and discussion later. 
Table 1. Monthly and annual mean temperature for four Asian cities (Unit: degree Celsius).

\begin{tabular}{ccccc}
\hline & Kuala Lumpur & Kolkata & Beijing & Ulan Bator \\
\hline January & 26.9 & 12.6 & -3.1 & -21.7 \\
February & 27.3 & 23.6 & 0.2 & -16.1 \\
March & 27.6 & 28.0 & 6.7 & -7.0 \\
April & 27.7 & 30.4 & 14.8 & 1.8 \\
May & 28.0 & 30.9 & 20.8 & 10.0 \\
June & 27.9 & 30.4 & 24.9 & 16.0 \\
July & 27.5 & 29.4 & 26.7 & 18.5 \\
August & 27.4 & 29.3 & 25.5 & 16.0 \\
September & 27.2 & 29.2 & 20.7 & 9.5 \\
October & 27.1 & 28.1 & 13.7 & 0.9 \\
November & 26.8 & 25.0 & 5.0 & -10.6 \\
December & 26.7 & 21.2 & -0.9 & -19.0 \\
Annual mean & 27.3 & 26.5 & 12.9 & -0.1 \\
\hline
\end{tabular}

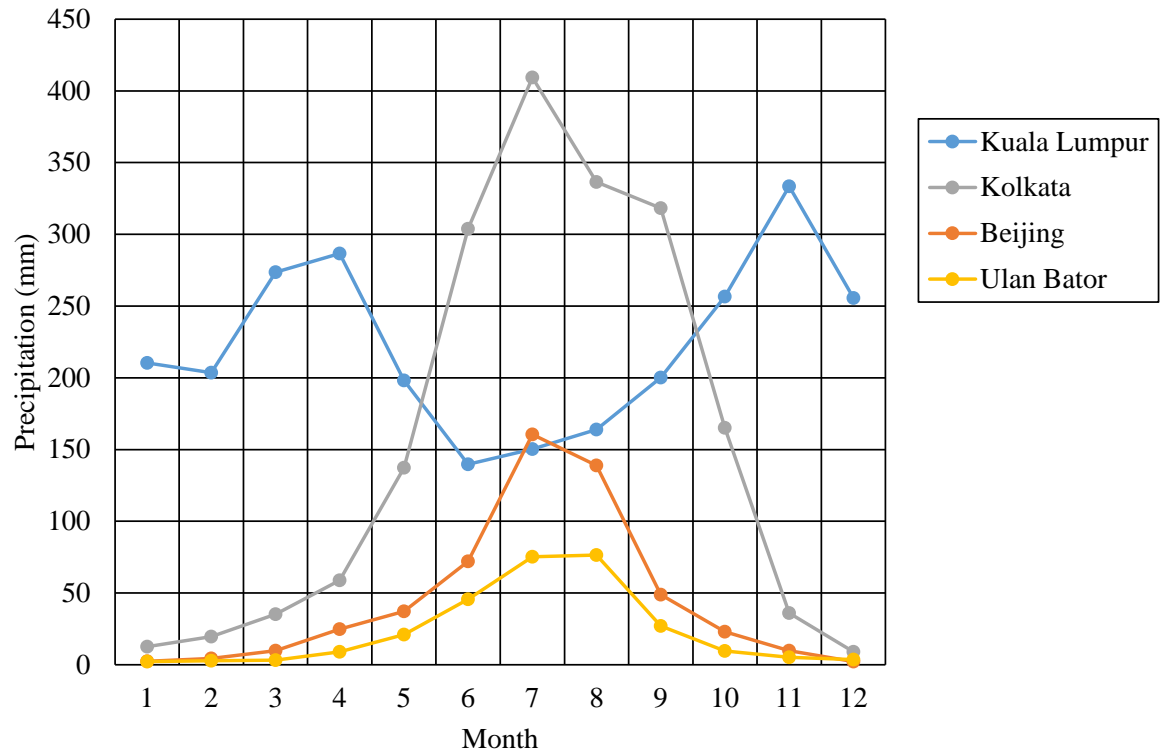

Figure 2. Monthly precipitation for four Asian cities.

\subsection{Estimation of $\mathbf{H}_{2}$ Produced by Water Electolysis}

The Type-S electrolyzer manufactured by IHT [32] [33] whose $\mathrm{H}_{2}$ production rate, power consumption and electrolysis efficiency are $760 \mathrm{Nm}^{3} / \mathrm{h}, 4.45$ $\mathrm{kHW} / \mathrm{Nm}^{3}$ and $79.5 \%$, is used in this study. The amount of $\mathrm{H}_{2}$ could be produced by the power generated from PV system is calculated by the following equation [1]:

$$
V_{H_{2}}=\frac{\eta_{e} E_{P V}}{P_{e}}
$$

where $V_{H 2}$ is amount of $\mathrm{H}_{2}$ produced $\left(\mathrm{Nm}^{3}\right), P_{e}$ is power consumption 
$\left(\mathrm{kWh} / \mathrm{Nm}^{3}\right), \quad \eta_{e}$ is electrolysis efficiency (-). In this study, it is assumed that the electrolyzer can be operated following the power generation characteristics of PV system every time and the produced $\mathrm{H}_{2}$ can be stored as well as used instantaneously.

It is assumed that the $\mathrm{H}_{2}$ produced by electolyzer would be used to generate power through a polymer electrolyte fuel cell (PEFC) system. $\mathrm{H}_{2}$ is converted into electricity by $\mathrm{FC}$ following the below equation [1]:

$$
\mathrm{H}_{2}+1 / 2 \mathrm{O}_{2}=\mathrm{H}_{2} \mathrm{O}+\eta_{f} Q
$$

where $\eta_{f}$ is power generation efficiency of latest PEFC stationary system based on lower heating value $(=0.39)$ [34], $Q$ is lower heating value of $\mathrm{H}_{2}(=242)$ $(\mathrm{kJ} / \mathrm{mol})$. It is assumed that the energy loss for operating pump to preserve and provide gases is ignored.

\subsection{Evaluation of Transportation Process}

It is necessary that the $\mathrm{H}_{2}$ produced by water electrolysis using the power generated by PV system is converted into a transportable media before shipped to Japan, due to low energy density of $\mathrm{H}_{2}$ in gas form. In this study, liquefaction and conversion of $\mathrm{H}_{2}$ into organic hydride are considered as the transportable media of $\mathrm{H}_{2}$.

In the case of liquefied $\mathrm{H}_{2}$ transportation, the volume of $\mathrm{H}_{2}$ is changed by $1 / 800$ by means of liquefaction [35]. Since the energy efficiency of liquefaction of $\mathrm{H}_{2}$ is $73.6 \%$ [36], the energy consumption of liquefaction is estimated by the energy efficiency and the amount of $\mathrm{H}_{2}$ to be liquefied. The volume of tank truck is $23 \mathrm{~m}^{3}$ [37] and the volume of tanker is $2500 \mathrm{~m}^{3}$ [38], which are leading-edge types. The fuel for tank truck is light oil and the fuel efficiency is $2.34 \mathrm{~km} / \mathrm{L}$ [39]. The fuel for tanker is heavy oil and the fuel efficiency is $0.87 \mathrm{~km} / \mathrm{L}$ [40]. The speed of the tanker is $36.1 \mathrm{~km} / \mathrm{h}$ [41] and the boil-off rate is $0.4 \% /$ day [38], which is used for counting $\mathrm{H}_{2}$ loss in marine transportation. The lower heating value of light oil and heavy oil are $35.5 \mathrm{MJ} / \mathrm{L}$ [42] and 46.4 MJ/L [43], respectively. The $\mathrm{CO}_{2}$ emission coefficient of light oil and heavy oil are $2.62 \mathrm{~kg}-\mathrm{CO}_{2} / \mathrm{L}$ [44] and $3.41 \mathrm{~kg}-\mathrm{CO}_{2} / \mathrm{L}$ [43], respectively. For land transportation, it is assumed to transport from the each city to the nearest sea port, then to Tokyo port in Japan through marine transportation by the tanker. The energy consumption of transportation as well as the amount of $\mathrm{CO}_{2}$ emission in the transportation process is estimated using the distance between each city and the nearest sea port as well as the sea port and Tokyo port in Japan.

In the case of organic hydride transportation, $\mathrm{H}_{2}$ can be transported by the volume of $1 / 500$ compared to the gases $\mathrm{H}_{2}$ at atmospheric pressure [35]. This study considers the reaction of $\mathrm{C}_{7} \mathrm{H}_{8}$ and $\mathrm{H}_{2}$ into $\mathrm{C}_{7} \mathrm{H}_{14}$ as the conversion process of organic hydride. Since the enthalpy loss of $\mathrm{C}_{7} \mathrm{H}_{14}$ for emitting $\mathrm{H}_{2}$, i.e., the necessary energy for emitting $\mathrm{H}_{2}$ which is an endothermic reaction is 67.5 $\mathrm{kJ} / \mathrm{mol}-\mathrm{H}_{2}$ [45]; the energy consumption of conversion process of organic hydride is estimated by the enthalpy loss and the amount of $\mathrm{H}_{2}$. In this study, the energy consumption of absorbing $\mathrm{H}_{2}$ is neglected since absorbing $\mathrm{H}_{2}$ by $\mathrm{C}_{7} \mathrm{H}_{8}$ is 
an exothermic reaction. Since the organic hydride can be transported by general tank truck and tanker for petroleum oil [46], this study assumes the volume of tank truck and tanker are $20 \mathrm{~m}^{3}$ [47] for land transportation and $20000 \mathrm{~m}^{3}$ [48] for marine transportation, respectively. The fuel for tank truck is light oil and the fuel efficiency is $2.34 \mathrm{~km} / \mathrm{L}$ [39]. The fuel for tanker is heavy oil and the fuel efficiency is $0.87 \mathrm{~km} / \mathrm{L}$ [40].

\section{Results and Discussion}

\subsection{Assessment on Characteristics of Large Scale PV System Assumed to be Installed in Four Cities}

At first, the optimum tilt angle and orientation angle to install solar panel for each city is investigated using the hourly meteorological data base [24] for the four Asian cities. The monthly and annual solar radiation are estimated summing the hourly data in order to decide the annual optimum tilt angle and orientation angle for power generation of PV system. After that, the power generation characteristics of PV system under the optimum tilt angle and orientation angle condition are investigated.

As an example, Figure 3 shows the relationship between tilt angle and amount of solar radiation for different orientation angles in the case of Kuala Lumpurin January. As to orientation angle, 0 degree means south and the angle increases by 30 degree in a clockwise fashion. Table 2 lists the annual amount of solar radiation for different tilt angles and orientation angles in the case of Kuala Lumpur. From this table, it is seen that the highest amount of solar radiation is obtained at tilt angle of 20 degree and orientation angle of 270 degree (i.e. east). Table 3 lists the annual amount of solar radiation for different tilt angles and orientation angles in the case of Kolkata. From this table, it is seen that the highest amount of solar radiation is obtained at tilt angle of 30 degree and orientation

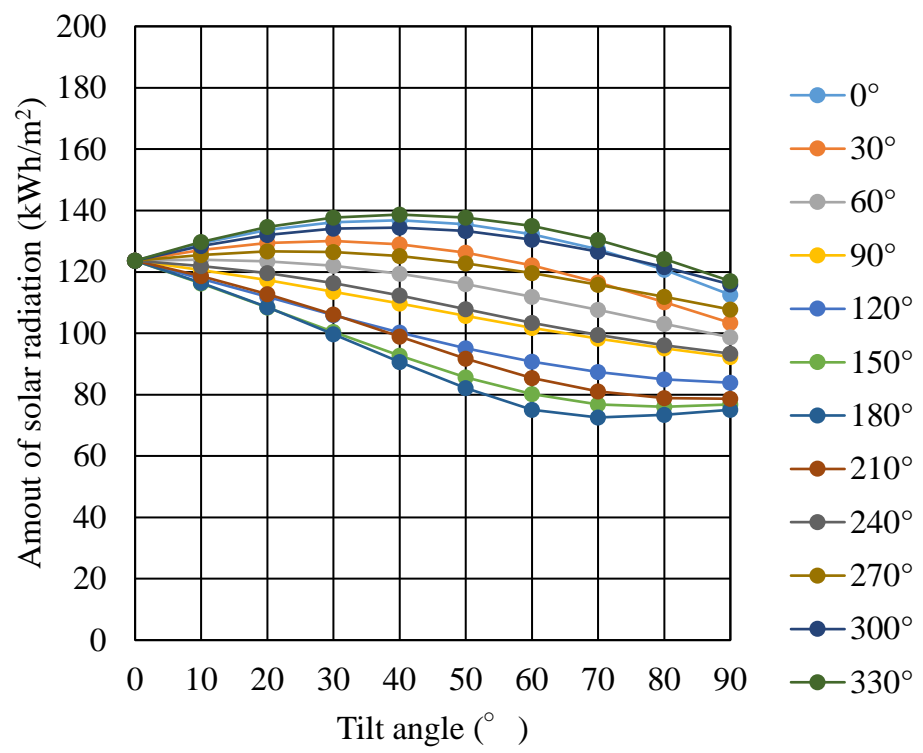

Figure 3. Relationship between tilt angle and amount of solar radiation for different orientation angles (Kuala Lumpur, January). 
Table 2. Annual amount of solar radiation for different tilt angles and orientation angles in the case of Kuala Lumpur (Unit: $\left.\mathrm{kWh} / \mathrm{m}^{2}\right)$.

\begin{tabular}{ccccccccccccc}
\hline & $0^{\circ}$ & $30^{\circ}$ & $60^{\circ}$ & $90^{\circ}$ & $120^{\circ}$ & $150^{\circ}$ & $180^{\circ}$ & $210^{\circ}$ & $240^{\circ}$ & $270^{\circ}$ & $300^{\circ}$ & $330^{\circ}$ \\
\hline $0^{\circ}$ & 1562 & 1562 & 1562 & 1562 & 1562 & 1562 & 1562 & 1562 & 1562 & 1562 & 1562 & 1562 \\
$10^{\circ}$ & 1557 & 1545 & 1538 & 1534 & 1534 & 1540 & 1550 & 1563 & 1574 & 1579 & 1577 & 1569 \\
$20^{\circ}$ & 1537 & 1517 & 1506 & 1501 & 1501 & 1506 & 1524 & 1550 & 1575 & 1588 & 1582 & 1562 \\
$30^{\circ}$ & 1498 & 1475 & 1467 & 1464 & 1458 & 1459 & 1480 & 1520 & 1561 & 1583 & 1573 & 1538 \\
$40^{\circ}$ & 1444 & 1420 & 1421 & 1422 & 1411 & 1401 & 1420 & 1474 & 1535 & 1565 & 1550 & 1498 \\
$50^{\circ}$ & 1375 & 1356 & 1370 & 1376 & 1360 & 1335 & 1348 & 1416 & 1497 & 1537 & 1515 & 1445 \\
$60^{\circ}$ & 1299 & 1288 & 1319 & 1332 & 1309 & 1268 & 1270 & 1351 & 1451 & 1499 & 1471 & 1383 \\
$70^{\circ}$ & 1221 & 1222 & 1269 & 1290 & 1261 & 1204 & 1197 & 1285 & 1401 & 1454 & 1421 & 1317 \\
$80^{\circ}$ & 1159 & 1163 & 1224 & 1249 & 1218 & 1151 & 1136 & 1224 & 1350 & 1407 & 1368 & 1254 \\
$90^{\circ}$ & 1110 & 1118 & 1186 & 1214 & 1183 & 1112 & 1091 & 1174 & 1301 & 1358 & 1317 & 1199 \\
\hline
\end{tabular}

Table 3. Annual amount of solar radiation for different tilt angles and orientation angles in the case of Kolkata $\left(\mathrm{Unit}: \mathrm{kWh} / \mathrm{m}^{2}\right)$.

\begin{tabular}{cccccccccccccc}
\hline & $0^{\circ}$ & $30^{\circ}$ & $60^{\circ}$ & $90^{\circ}$ & $120^{\circ}$ & $150^{\circ}$ & $180^{\circ}$ & $210^{\circ}$ & $240^{\circ}$ & $270^{\circ}$ & $300^{\circ}$ & $330^{\circ}$ \\
\hline $0^{\circ}$ & 1582 & 1582 & 1582 & 1582 & 1582 & 1582 & 1582 & 1582 & 1582 & 1582 & 1582 & 1582 \\
$10^{\circ}$ & 1642 & 1630 & 1604 & 1570 & 1536 & 1511 & 1504 & 1518 & 1548 & 1583 & 1615 & 1637 \\
$20^{\circ}$ & 1686 & 1665 & 1619 & 1555 & 1486 & 1432 & 1416 & 1446 & 1509 & 1580 & 1639 & 1677 \\
$30^{\circ}$ & 1706 & 1679 & 1619 & 1532 & 1430 & 1344 & 1315 & 1366 & 1463 & 1566 & 1647 & 1695 \\
$40^{\circ}$ & 1702 & 1672 & 1605 & 1502 & 1373 & 1254 & 1212 & 1283 & 1413 & 1543 & 1637 & 1690 \\
$50^{\circ}$ & 1673 & 1643 & 1576 & 1466 & 1317 & 1171 & 1120 & 1204 & 1363 & 1513 & 1614 & 1663 \\
$60^{\circ}$ & 1621 & 1596 & 1537 & 1426 & 1268 & 1104 & 1050 & 1139 & 1317 & 1476 & 1576 & 1617 \\
$70^{\circ}$ & 1549 & 1533 & 1488 & 1385 & 1227 & 1057 & 1001 & 1092 & 1276 & 1436 & 1527 & 1552 \\
$80^{\circ}$ & 1462 & 1459 & 1433 & 1345 & 1194 & 1030 & 974 & 1065 & 1241 & 1392 & 1470 & 1475 \\
$90^{\circ}$ & 1370 & 1380 & 1377 & 1305 & 1171 & 1024 & 969 & 1054 & 1213 & 1348 & 1409 & 1393 \\
\hline
\end{tabular}

angle of 0 degree (i.e. south). Table 4 lists the annual amount of solar radiation for different tilt angles and orientation angles in the case of Beijing. From this table, it is seen that the highest amount of solar radiation is obtained at tilt angle of 50 degree and orientation angle of 0 degree (i.e. south). Table 5 lists the annual amount of solar radiation for different tilt angles and orientation angles in the case of Ulan Bator. From this table, it is seen that the highest amount of solar radiation is obtained at tilt angle of 60 degree and orientation angle of 0 degree (i.e. south).

According to Tables 2-5, the optimum tilt angel increases with increasing latitude. In addition, the optimum orientation angle is 0 degree except Kuala Lumpur. Kuala Lumpur is located near the equator and the solar altitude is the highest on the spring equinox day and the autumnal equinox day, which are different from the other cities. Therefore, the optimum orientation angle for Kuala Lumpur would be different compared to the other cities. The power of PV system is estimated under the condition installing solar panel at this optimum tilt angle and orientation angle.

Figure 4 shows the monthly electricity generated by the PV system in the four 
A. Nishimura et al.

Table 4. Annual amount of solar radiation for different tilt angles and orientation angles in the case of Beijing $\left(\mathrm{Unit}: \mathrm{kWh} / \mathrm{m}^{2}\right)$.

\begin{tabular}{cccccccccccccc}
\hline & $0^{\circ}$ & $30^{\circ}$ & $60^{\circ}$ & $90^{\circ}$ & $120^{\circ}$ & $150^{\circ}$ & $180^{\circ}$ & $210^{\circ}$ & $240^{\circ}$ & $270^{\circ}$ & $300^{\circ}$ & $330^{\circ}$ \\
\hline $0^{\circ}$ & 1389 & 1389 & 1389 & 1389 & 1389 & 1389 & 1389 & 1389 & 1389 & 1389 & 1389 & 1389 \\
$10^{\circ}$ & 1496 & 1478 & 1436 & 1379 & 1322 & 1280 & 1268 & 1289 & 1337 & 1396 & 1450 & 1486 \\
$20^{\circ}$ & 1589 & 1557 & 1482 & 1377 & 1264 & 1174 & 1145 & 1191 & 1291 & 1407 & 1508 & 1573 \\
$30^{\circ}$ & 1658 & 1616 & 1516 & 1374 & 1212 & 1074 & 1029 & 1098 & 1248 & 1414 & 1551 & 1636 \\
$40^{\circ}$ & 1700 & 1650 & 1536 & 1368 & 1168 & 989 & 937 & 1019 & 1211 & 1415 & 1578 & 1677 \\
$50^{\circ}$ & 1712 & 1661 & 1541 & 1358 & 1134 & 927 & 865 & 960 & 1182 & 1409 & 1585 & 1690 \\
$60^{\circ}$ & 1697 & 1647 & 1528 & 1343 & 1109 & 889 & 817 & 923 & 1159 & 1396 & 1577 & 1677 \\
$70^{\circ}$ & 1654 & 1609 & 1502 & 1322 & 1092 & 876 & 795 & 909 & 1143 & 1376 & 1548 & 1639 \\
$80^{\circ}$ & 1585 & 1550 & 1460 & 1296 & 1080 & 880 & 803 & 910 & 1129 & 1350 & 1505 & 1578 \\
$90^{\circ}$ & 1494 & 1472 & 1406 & 1264 & 1071 & 895 & 829 & 922 & 1118 & 1316 & 1448 & 1497 \\
\hline
\end{tabular}

Table 5. Annual amount of solar radiation for different tilt angles and orientation angles in the case of Ulan Bator (Unit: $\left.\mathrm{kWh} / \mathrm{m}^{2}\right)$.

\begin{tabular}{|c|c|c|c|c|c|c|c|c|c|c|c|c|}
\hline & $0^{\circ}$ & $30^{\circ}$ & $60^{\circ}$ & $90^{\circ}$ & $120^{\circ}$ & $150^{\circ}$ & $180^{\circ}$ & $210^{\circ}$ & $240^{\circ}$ & $270^{\circ}$ & $300^{\circ}$ & $330^{\circ}$ \\
\hline $0^{\circ}$ & 1329 & 1329 & 1329 & 1329 & 1329 & 1329 & 1329 & 1329 & 1329 & 1329 & 1329 & 1329 \\
\hline $10^{\circ}$ & 1467 & 1458 & 1412 & 1343 & 1267 & 1207 & 1177 & 1189 & 1239 & 1310 & 1382 & 1440 \\
\hline $20^{\circ}$ & 1592 & 1575 & 1490 & 1359 & 1211 & 1089 & 1031 & 1061 & 1163 & 1300 & 1436 & 1542 \\
\hline $30^{\circ}$ & 1691 & 1667 & 1550 & 1367 & 1158 & 983 & 910 & 952 & 1099 & 1291 & 1477 & 1620 \\
\hline $50^{\circ}$ & 1796 & 1766 & 1609 & 1364 & 1080 & 839 & 746 & 810 & 1016 & 1268 & 1510 & 1699 \\
\hline $60^{\circ}$ & 1799 & 1771 & 1609 & 1354 & 1061 & 812 & 706 & 783 & 994 & 1251 & 1501 & 1697 \\
\hline $70^{\circ}$ & 1769 & 1744 & 1585 & 1336 & 1050 & 811 & 704 & 782 & 982 & 1230 & 1475 & 1666 \\
\hline $80^{\circ}$ & 1707 & 1688 & 1546 & 1312 & 1045 & 826 & 732 & 796 & 976 & 1203 & 1432 & 1610 \\
\hline
\end{tabular}

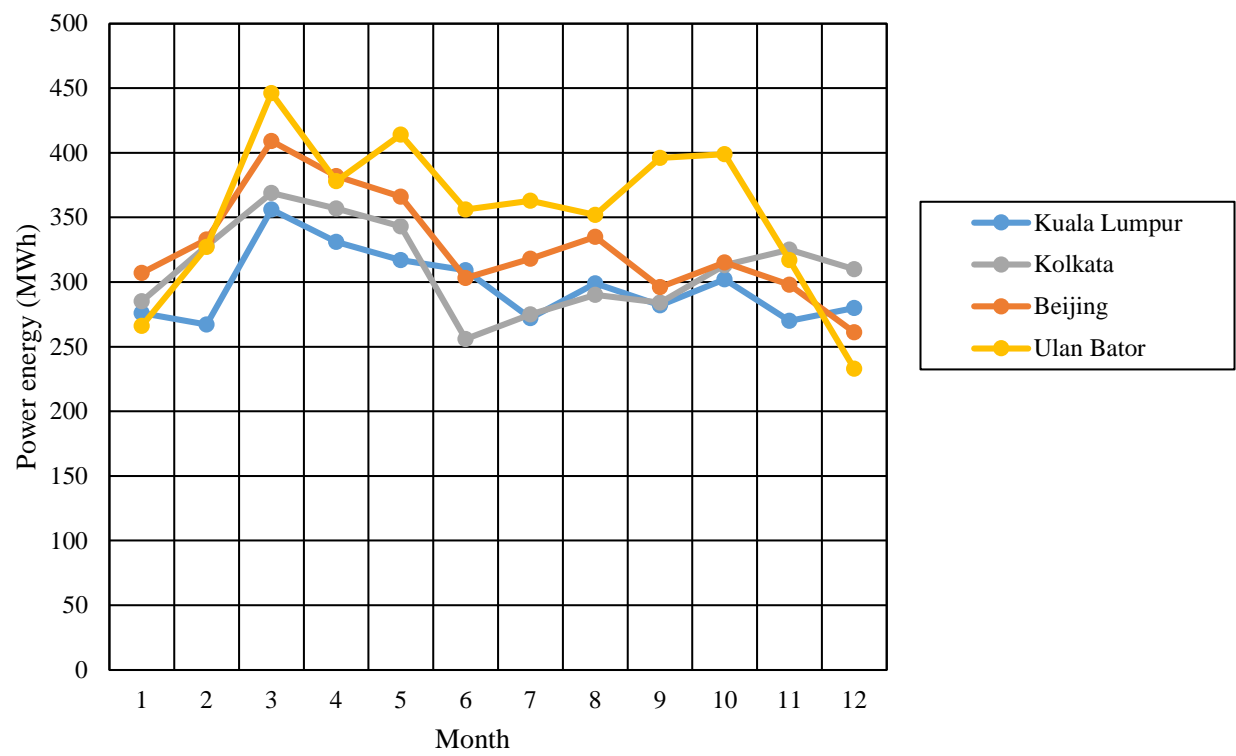

Figure 4. Monthly electricity generated by PV system for four Asian cities. 
cities. In this estimation, it was assumed that the PV system consists of 10,000 solar panels $(=2.5 \mathrm{MW}$; one panel $=0.25 \mathrm{~kW})$. The annual electricity generated by the PV system for Kuala Lumpur, Kolkata, Beijing and Ulan Bator are 3.56 GWh, 3.74 GWh, 3.92 GWh and 4.25 GWh, respectively.

According to Figure 4, it is seen that with the same solar PV panels, the PV system in Ulan Bator could be generated the largest amount of annual power output due to its lower annual mean ambient temperature and precipitation. On the other hand, in the case of Kuala Lumpur, the annual mean temperature and annual precipitation are the highest among the four cities, thus generating the smallest annual power output. In addition, it is revealed from Figure 4 that the monthly electricity generated by the PV system is the highest in March irrespective of city.

\subsection{Assessment on $\mathrm{H}_{2}$ Production by Water Electrolysis and Transportation by Liquefied $\mathrm{H}_{2}$ from Each City to Tokyo}

Table 6 lists the monthly amount of produced $\mathrm{H}_{2}$ by water electrolysis using the electricity generated by PV system consisting of 10,000 PV panels or modules having total peak capacity of $2.5 \mathrm{MW}$, assumed to be installed in four cities. The annual amount of $\mathrm{H}_{2}$ produced by water elerctrolys is using the electricity generated by the PV system installed in Kuala Lumpur, Kolkata, Beijing and Ulan Bator are 28.4 Mmol, 29.8 Mmol, 31.3 Mmol and 33.9 Mmol, respectively.

Table 6 also lists the decreased volume of liquefied $\mathrm{H}_{2}$ by boil-off rate. It increases with increasing marine transportation distance and total amount of liquefied $\mathrm{H}_{2}$.

According to Table 6, the largest amount of produced $\mathrm{H}_{2}$ could be delivered to Tokyo is obtained in the case of Ulan Bator, while the smallest amount is obtained in the case of Kuala Lumpur. These results follow the characteristics of electricity generated by the PV system shown in Figure 3.

Table 7 lists the annual amount of produced $\mathrm{H}_{2}$, the volume of liquefied $\mathrm{H}_{2}$,

Table 6. Monthly amount of produced $\mathrm{H}_{2}$ and delivered in Tokyo from four Asian cities.

\begin{tabular}{|c|c|c|c|c|c|c|c|c|c|c|c|c|c|c|}
\hline & Month & Jan. & Feb. & Mar. & Apr. & May & Jun. & Jul. & Aug. & Sep. & Oct. & Nov. & Dec. & Annual \\
\hline \multirow{2}{*}{ Kuala Lumpur } & Amount of produced $\mathrm{H}_{2}(\mathrm{Mmol})$ & 2.21 & 2.13 & 2.84 & 2.64 & 2.52 & 2.46 & 2.17 & 2.39 & 2.25 & 2.41 & 2.16 & 2.23 & 28.4 \\
\hline & $\begin{array}{l}\text { Decreased volume of liquefied } \mathrm{H}_{2} \\
\text { by boil-off rate }\left(\mathrm{m}^{3} / \text { year }\right)\end{array}$ & & & & & & & & & & & & & 22.3 \\
\hline \multirow[b]{2}{*}{ Kolkata } & Amount of produced $\mathrm{H}_{2}(\mathrm{Mmol})$ & 2.27 & 2.61 & 2.94 & 2.84 & 2.74 & 2.05 & 2.20 & 2.32 & 2.27 & 2.49 & 2.59 & 2.47 & 29.8 \\
\hline & $\begin{array}{l}\text { Decreased volume of liquefied } \mathrm{H}_{2} \\
\text { by boil-off rate }\left(\mathrm{m}^{3} / \text { year }\right)\end{array}$ & & & & & & & & & & & & & 33.4 \\
\hline \multirow[b]{2}{*}{ Beijing } & Amount of produced $\mathrm{H}_{2}(\mathrm{Mmol})$ & 2.45 & 2.66 & 3.27 & 3.05 & 2.92 & 2.42 & 2.54 & 2.67 & 2.36 & 2.51 & 2.37 & 2.08 & 31.3 \\
\hline & $\begin{array}{l}\text { Decreased volume of liquefied } \mathrm{H}_{2} \\
\text { by boil-off rate }\left(\mathrm{m}^{3} / \text { year }\right)\end{array}$ & & & & & & & & & & & & & 14.0 \\
\hline \multirow[b]{2}{*}{ Ulan Bator } & Amount of produced $\mathrm{H}_{2}(\mathrm{Mmol})$ & 2.13 & 2.61 & 3.56 & 3.02 & 3.30 & 2.84 & 2.90 & 2.81 & 3.16 & 3.18 & 2.53 & 1.86 & 33.9 \\
\hline & $\begin{array}{l}\text { Decreased volume of liquefied } \mathrm{H}_{2} \\
\text { by boil-off rate }\left(\mathrm{m}^{3} / \text { year }\right)\end{array}$ & & & & & & & & & & & & & 15.2 \\
\hline
\end{tabular}


Table 7. Transportation and conversion characteristics from four Asian cities ( $\mathrm{H}_{2}$ liquefaction).

\begin{tabular}{|c|c|c|c|c|}
\hline & Kuala Lumpur & Kolkata & Beijing & Ulan Bator \\
\hline Annual amount of produced $\mathrm{H}_{2}\left(\mathrm{Nm}^{3} /\right.$ year $)$ & $6.362 \times 10^{5}$ & $6.673 \times 10^{5}$ & $7.011 \times 10^{5}$ & $7.591 \times 10^{5}$ \\
\hline Volume of liquefied $\mathrm{H}_{2}\left(\mathrm{~m}^{3} /\right.$ year $)$ & 795.2 & 834.1 & 876.4 & 948.9 \\
\hline Number of tank truck (-) & 35 & 37 & 39 & 42 \\
\hline Amount of $\mathrm{CO}_{2}$ emission for all tank truck $\left(\mathrm{kg}-\mathrm{CO}_{2}\right)$ & $2.35 \times 10^{3}$ & $3.73 \times 10^{3}$ & $7.42 \times 10^{3}$ & $7.05 \times 10^{5}$ \\
\hline Energy consumption for all tank truck (GJ) & 31.9 & 50.5 & 100.6 & 9557.7 \\
\hline Number of tanker $(-)$ & 0.319 & 0.334 & 0.351 & 0.380 \\
\hline Amount of $\mathrm{CO}_{2}$ emission for a tanker $\left(\mathrm{kg}-\mathrm{CO}_{2}\right)$ & $2.05 \times 10^{4}$ & $2.95 \times 10^{4}$ & $1.04 \times 10^{4}$ & $1.04 \times 10^{4}$ \\
\hline Energy consumption for a tanker (GJ) & 277.9 & 400.4 & 141.3 & 141.3 \\
\hline Energy consumption in all transportation process (GJ) & 310 & 451 & 242 & 9699 \\
\hline Amount of $\mathrm{CO}_{2}$ emission in all transportation process $\left(\mathrm{kg}-\mathrm{CO}_{2}\right)$ & $2.3 \times 10^{4}$ & $3.3 \times 10^{4}$ & $1.8 \times 10^{4}$ & $71.6 \times 10^{4}$ \\
\hline Energy consumption for liquefaction (GJ) & 1764 & 1827 & 1968 & 2131 \\
\hline Total energy consumption (GJ) & $2.07 \times 10^{3}$ & $2.28 \times 10^{3}$ & $2.21 \times 10^{3}$ & $11.83 \times 10^{3}$ \\
\hline Electricity generated by FC in Tokyo (after transportation) (GWh) & 0.722 & 0.750 & 0.807 & 0.874 \\
\hline Ratio of total energy consumption to calorific value of $\mathrm{H}_{2}$ delivered to Tokyo (-) & 0.310 & 0.329 & 0.296 & 1.466 \\
\hline
\end{tabular}

Table 8. The nearest port, land transportation distance, marine transportation distance and marine transportation days for four Asian cities.

\begin{tabular}{|c|c|c|c|c|}
\hline & Kuala Lumpur & Kolkata & Beijing & Ulan Bator \\
\hline The nearest port & Port Klang & Haldia & Tianjin & Tianjin \\
\hline Marine transportation distance $(\mathrm{km})$ & 5900 & 8500 & 3000 & 3000 \\
\hline Marine transportation days & 7 & 10 & 4 & 4 \\
\hline
\end{tabular}

the number of tank truck transporting for all liquefied $\mathrm{H}_{2}$, the amount of $\mathrm{CO}_{2}$ emission for all tank truck and the energy consumption for all tank truck for four Asian cities. In addition, Table 7 also lists the number of tanker transporting for all liquefied $\mathrm{H}_{2}$, the amount of $\mathrm{CO}_{2}$ emission for a tanker, the energy consumption for a tanker, the energy consumption in all transportation process, the amount of $\mathrm{CO}_{2}$ emission in all transportation process, the energy consumption for liquefaction, the electricity generated by FC in Tokyo (after transportation), the total energy consumption and the ratio of total energy consumption to calorific value of $\mathrm{H}_{2}$ delivered in Tokyo for four Asian cities. In this estimation, the 2.5 MW PV system was assumed to be installed in the source cities.

According to Table 7, it is revealed that the largest amount of $\mathrm{CO}_{2}$ emission and energy consumption for all tank truck are obtained in the case of Ulan Bator, while the smallest amount of $\mathrm{CO}_{2}$ emission and energy consumption for all tank truck are obtained in the case of Kuala Lumpur. Since the distance from Ulan Bator to the nearest seaport is very long according to Table 8 [49] and more number of tank truck is needed compared to the other cities, the amount of $\mathrm{CO}_{2}$ emission and energy consumption for all tank truck are larger in the case 
of Ulan Bator. On the other hand, the distance from Kuala Lumpur to the nearest seaport is the shortest and the number of tank truck is also the fewest among four cities, resulting that the amount of $\mathrm{CO}_{2}$ emission and energy consumption for all tank truck are smaller in the case of Kuala Lumpur.

As to marine transportation, it is revealed that the largest amount of $\mathrm{CO}_{2}$ emission and energy consumption for a tanker are obtained in the case of Kolkata, while the smallest amount of $\mathrm{CO}_{2}$ emission and energy consumption for a tanker are obtained in the case of Beijing and Kuala Lumpur. In this study, the amount of $\mathrm{CO}_{2}$ emission and energy consumption for a tanker depend on marine transportation distance only. Since the marine transportation distance in the case of Kolkata is the longest and those in the case of Beijing and Kuala Lumpur are the shortest among four cities, the above mentioned characteristics on marine transportation are lead.

As to all transportation process, it is revealed that the largest amount of $\mathrm{CO}_{2}$ emission and energy consumption are obtained in the case of Ulan Bator since the impact of land transportation is significant. On the other hand, it is seen that the smallest amount of $\mathrm{CO}_{2}$ emission and energy consumption are obtained in the case of Beijing. Though the impact of land transportation is not small in the case of Beijing, it is believed that this result is obtained by smaller impact of the marine transportation compared to the other cities.

It is known that the electricity generated by the FC system is about $20 \%$ of that by the PV system under the assumption of this study. Since the amount of energy is decreased by energy conversion, it is important to transport the large amount of $\mathrm{H}_{2}$ for fulfilling the energy demand of remote country.

Table 7 reveals that the total energy consumption during the transportation and the ratio of total energy consumption to calorific value of $\mathrm{H}_{2}$ delivered are the largest in the case of Ulan Bator, while they are the smallest in the case of Beijing. In the case of Ulan Bator, the ratio is even greater than 1 which means it would cost more energy to transport $\mathrm{H}_{2}$ than energy (contained in $\mathrm{H}_{2}$ ) delivered. Table 7 implies Beijing is the best energy effective case.

\subsection{Assessment on $\mathrm{H}_{2}$ Production by Water Electrolysis and Transportation by Organic Hydride from Each City to Tokyo}

Table 9 lists the annual amount of produced $\mathrm{H}_{2}$, the volume of organic hydride, the number of tank truck transporting for all organic hydride, the amount of $\mathrm{CO}_{2}$ emission for all tank truck and the energy consumption for all tank truck for four Asian cities. In addition, Table 9 also lists the number of tanker transporting for all organic hydride, the amount of $\mathrm{CO}_{2}$ emission for a tanker, the energy consumption for a tanker, the energy consumption in all transportation process, the amount of $\mathrm{CO}_{2}$ emission in all transportation process, the energy consumption for liquefaction, the electricity generated by FC in Tokyo (after transportation), the total energy consumption and the ratio of total energy consumption to calorific value of $\mathrm{H}_{2}$ after transportation for four Asian cities. In this estimation, the monthly amount of produced $\mathrm{H}_{2}$ by water electrolysis using the 
Table 9. Transportation and conversion characteristics for four Asian cities (organic hydride).

\begin{tabular}{|c|c|c|c|c|}
\hline & Kuala Lumpur & Kolkata & Beijing & Ulan Bator \\
\hline Annual amount of produced $\mathrm{H}_{2}\left(\mathrm{Nm}^{3} /\right.$ year $)$ & $6.362 \times 10^{5}$ & $6.673 \times 10^{5}$ & $7.011 \times 10^{5}$ & $7.591 \times 10^{5}$ \\
\hline Volume of organic hydride $\left(\mathrm{m}^{3} /\right.$ year $)$ & 1272.3 & 1334.6 & 1402.2 & 1518.3 \\
\hline Number of tank truck (-) & 64 & 67 & 71 & 76 \\
\hline Amount of $\mathrm{CO}_{2}$ emission for all tank truck $\left(\mathrm{kg}-\mathrm{CO}_{2}\right)$ & $4.30 \times 10^{3}$ & $6.75 \times 10^{3}$ & $13.51 \times 10^{3}$ & $12.76 \times 10^{5}$ \\
\hline Energy consumption for all tank truck (GJ) & 58.3 & 91.5 & 183.1 & $172.9 \times 10^{2}$ \\
\hline Number of tanker (-) & 0.0637 & 0.0688 & 0.0702 & 0.0760 \\
\hline Amount of $\mathrm{CO}_{2}$ emission for a tanker $\left(\mathrm{kg}-\mathrm{CO}_{2}\right)$ & $2.05 \times 10^{4}$ & $2.95 \times 10^{4}$ & $1.04 \times 10^{4}$ & $1.04 \times 10^{4}$ \\
\hline Energy consumption for a tanker (GJ) & 277.9 & 400.4 & 141.3 & 141.3 \\
\hline Energy consumption in all transportation process (GJ) & 336 & 492 & 324 & $174.4 \times 10^{2}$ \\
\hline Amount of $\mathrm{CO}_{2}$ emission in all transportation process $\left(\mathrm{kg}-\mathrm{CO}_{2}\right)$ & $2.5 \times 10^{4}$ & $3.6 \times 10^{4}$ & $2.4 \times 10^{4}$ & $128.6 \times 10^{4}$ \\
\hline Energy consumption for conversion of organic hydride (GJ) & 1917 & 2011 & 2113 & 2288 \\
\hline Total energy consumption (GJ) & $2.25 \times 10^{3}$ & $2.50 \times 10^{3}$ & $2.44 \times 10^{3}$ & $19.73 \times 10^{3}$ \\
\hline Electricity generated by FC in Tokyo (after transportation) (GWh) & 0.743 & 0.781 & 0.820 & 0.888 \\
\hline $\begin{array}{l}\text { Ratio of total energy consumption to calorific value of } \mathrm{H}_{2} \text { delivered to } \\
\text { Tokyo (-) }\end{array}$ & 0.328 & 0.347 & 0.322 & 2.405 \\
\hline
\end{tabular}

electricity generated by the PV system consisting of 10,000 PV panels or modules having total peak capacity of $2.5 \mathrm{MW}$ as shown in Table 6 is used.

According to Table 9, it is revealed that the largest amount of $\mathrm{CO}_{2}$ emission and energy consumption for all tank truck are obtained in the case of Ulan Bator, while the smallest amount of $\mathrm{CO}_{2}$ emission and energy consumption for all tank truck are obtained in the case of Kuala Lumpur, which is the same tendency as $\mathrm{H}_{2}$ liquefaction case. Since the distance from Ulan Bator to the nearest sea port is very long according to Table 8 [49] and more number of tank truck is needed compared to the other cities, the amount of $\mathrm{CO}_{2}$ emission and energy consumption for all tank truck are larger in the case of Ulan Bator. On the other hand, the distance from Kuala Lumpur to the nearest sea port is the shortest and the number of tank truck is also the fewest among four cities, resulting that the amount of $\mathrm{CO}_{2}$ emission and energy consumption for all tank truck are smaller in the case of Kuala Lumpur.

As to marine transportation, it is revealed that the largest amount of $\mathrm{CO}_{2}$ emission and energy consumption for a tanker are obtained in the case of Kolkata, while the smallest amount of $\mathrm{CO}_{2}$ emission and energy consumption for a tanker are obtained in the case of Beijing and Kuala Lumpur, which can be explained by the same discussion as $\mathrm{H}_{2}$ liquefaction case. In this study, the amount of $\mathrm{CO}_{2}$ emission and energy consumption for a tanker depend on marine transportation distance only. Since the marine transportation distance in the case of Kolkata is the longest and that in the case of Beijing and Kuala Lumpur is the shortest among four cities, the above mentioned characteristics on marine transportation are obtained. 
As to all transportation process, it is revealed that the largest amount of $\mathrm{CO}_{2}$ emission and energy consumption are obtained in the case of Ulan Bator, while it is seen that the smallest amount of $\mathrm{CO}_{2}$ emission and energy consumption are obtained in the case of Beijing, which can be explained by the same discussion as $\mathrm{H}_{2}$ liquefaction case.

After delivered in Tokyo by organic hydride, the electricity generated by FC system is about $21 \%$ of that by the PV system under the assumption of this study.

Table 9 reveals that the total energy consumption and the ratio of total energy consumption to calorific value of $\mathrm{H}_{2}$ delivered are the largest in the case of Ulan Bator, while those are the smallest in the case of Beijing, which is the same tendency as $\mathrm{H}_{2}$ liquefaction case. Since the annual amount of produced $\mathrm{H}_{2}$ in the case of Beijing is the largest compared to the other cities except Ulan Bator and the energy consumption in all transportation process is the smallest among four cities, Beijing is the best energy effective case.

Comparing the ratio of total energy consumption to calorific value of $\mathrm{H}_{2}$ delivered between $\mathrm{H}_{2}$ liquefaction case and organic hydride case, the ratio in the case of $\mathrm{H}_{2}$ liquefaction is smaller than that in the case of organic hydride. When converting gases $\mathrm{H}_{2}$ into liquefied $\mathrm{H}_{2}$ or organic hydride, the volume ratios of $\mathrm{H}_{2}$ liquefaction and conversion into organic hydride are $1 / 800$ and $1 / 500$, respectively. Therefore, the converted volume after $\mathrm{H}_{2}$ liquefaction is smaller than that after conversion into organic hydride. In addition, the volume of tank truck for liquefied $\mathrm{H}_{2}$ is larger than that for organic hydride, resulting that the number of tank truck for land transportation of liquefied $\mathrm{H}_{2}$ is smaller. Consequently, the ratio of total energy consumption to calorific value of $\mathrm{H}_{2}$ after transportation in the case of $\mathrm{H}_{2}$ liquefaction is smaller than that in the case of organic hydride due to impact of land transportation.

From the investigation of this study, it is revealed that the proposed energy supply chain is the optimum in the case of Beijing. On the other hand, the introduction of proposed energy supply chain is not effective in the case of Ulan Bator due to very long land transportation distance.

\section{Conclusions}

This study proposed an energy supply chain which consists of solar panels, water electrolyzer, $\mathrm{H}_{2}$ liquefaction process (or conversion process from $\mathrm{H}_{2}$ into organic hydride), transportation by tank truck for land as well as tanker for marine and FC. This study investigated the electricity generated by PV system assumed to be installed in four Asian cities using the meteorological data and the amount of $\mathrm{H}_{2}$ produced by water electrolysis using the electricity generated by PV system. This study also investigated the energy efficiency of the proposed energy supply chain and the amount of $\mathrm{CO}_{2}$ emission in the transportation process. As a result, the following conclusions have been drawn:

1) The largest amount of electricity generated from the same size PV systems is obtained in the case of Ulan Bator, while the smallest amount of electricity 
generated by the PV system is obtained in the case of Kuala Lumpur. The monthly electricity generated by the PV system is the highest in March irrespective of city investigated.

2) When assuming $2.5 \mathrm{MW} \mathrm{PV}$ panel installed in four cities in the case of $\mathrm{H}_{2}$ liquefaction, the annual electricity could be generated by the FC system in Tokyo is $0.722 \mathrm{GWh}, 0.750 \mathrm{GWh}, 0.807 \mathrm{GWh}$ and $0.874 \mathrm{GWh}$, in the cases of Kuala Lumpur, Kolkata, Beijing and Ulan Bator, respectively. The electricity generated by the FC system in Tokyo is about $20 \%$ of the electricity generated by the PV system in the source cities. On the other hand, in the case of organic hydride, the annual electricity could be generated by the FC system in Tokyo is $0.743 \mathrm{GWh}, 0.781 \mathrm{GWh}, 0.820 \mathrm{GWh}$ and $0.888 \mathrm{GWh}$, in the cases of Kuala Lumpur, Kolkata, Beijing and Ulan Bator, respectively. The electricity generated by the FC system is about $21 \%$ of that by PV system in source cities.

3) As expected the $\mathrm{CO}_{2}$ emission from the transportation from Ulan Batorto, Tokyo is the largest among that from four cities due to long land transportation distance.

4) Comparing the ratio of total energy consumption to calorific value of $\mathrm{H}_{2}$ delivered between $\mathrm{H}_{2}$ liquefaction case and organic hydride case, the ratio of total energy consumption to calorific value of $\mathrm{H}_{2}$ delivered in the case of $\mathrm{H}_{2}$ liquefaction is generally smaller than that in the case of organic hydride.

5) The proposed energy supply chain from Beijing to Tokyo is the optimum, while the chain from Ulan Bator to Tokyo is not energy effective at all due to very long land transportation distance.

\section{References}

[1] Nishimura, A., Kitagawa, S., Hirota, M. and Hu, E. (2017) Assessment on Energy Self-Sufficiency Rate for Building Integrated Photovoltaics and Fuel Cell System in Japan. Smart Grid and Renewable Energy, In Press.

[2] Ogimoto, K. (2015) Hydrogen Production from Curtailed Renewable Energy Electricity. Hydrogen Energy System, 40, 196-201.

[3] Nakata, H. and Kaya, Y. (1995) Model Evaluation of $\mathrm{CO}_{2}$ Reduction Technologies in the Asia-Pacific Region. Electrical Engineering in Japan, 115, 65-74. https://doi.org/10.1002/eej.4391150506

[4] Scheiebahn, S., Grube, T., Robinius, M., Tietze, V., Kumar, B. and Stolen, D. (2015) Power to Gas: Technologies Overview, System Analysis and Economic Assessment for a Case Study in Germany. International Journal of Hydrogen Energy, 40, 42854294. https://doi.org/10.1016/j.ijhydene.2015.01.123

[5] Ehteshami, S.M.M. and Chan, S.H. (2014) The Role of Hydrogen and Fuel Cells to Store Renewable Energy in the Future Energy Network-Potentials and Challenges. Energy Policy, 73, 103-109. https://doi.org/10.1016/j.enpol.2014.04.046

[6] Naish, C., McCubbin, I., Edberg, O. and Harfoot, M. (2008) Outlook of Energy Storage Technologies. Report to European Parliament. http://www.europarl.europa.eu/document/

[7] Kumagai, N. (2016) Mass Transportation of Renewable Energy Based on Methanation Technology. Proceedings of the 3rd Hydrogen Energy Lecture Meeting in the 
Japan Institute of Energy, 16 December 2016, 221-235.

[8] Caliskan, H., Diner, I. and Hepbasli, A. (2013) Energy, Exergy and Sustainability Analysis of Hybrid Renewable Energy Based Hydrogen and Electricity Production and Storage Systems: Modeling and Case Study. Applied Thermal Engineering, 61, 784-798. https://doi.org/10.1016/j.applthermaleng.2012.04.026

[9] Wu, W., Lin, M.H. and Chen, W.H. (2015) Exergy Analysis of an EFC/PV/ BatteryBased Hybrid Power Generation System. Energy Research, 39, 406-417. https://doi.org/10.1002/er.3258

[10] Esmaili, P., Dincer, I. and Naterer, G.F. (2015) Development and Analysis of an Integrated Photovoltaic System for Hydrogen and Methanol Production. International Journal of Hydrogen Energy, 40, 11140-11153. https://doi.org/10.1016/j.ijhydene.2015.04.077

[11] Licht, S., Chitayat, O., Bergmann, H., Dick, A., Ayub, H. and Ghosh, S. (2010) Efficient STEP (Solar Thermal Electrochemical Photo) Production of Hydrogen-An Economic Assessment. International Journal of Hydrogen Energy, 35, 10867-10882. https://doi.org/10.1016/j.ijhydene.2010.07.028

[12] Marino, C., Nucara, A., Pietrafesa, M. and Pudano, A. (2013) An Energy Self-Sufficient Building Using Integrated Renewable Sources and Hydrogen Storage. Energy, 57, 95-105. https://doi.org/10.1016/j.energy.2013.01.053

[13] Maleki, A. and Askarzadeh, A. (2014) Comparative Study of Artificial Intelligence Techniques for Sizing of a Hydrogen-Based Stand-Alone Photovoltaic/Wind Hybrid System. International Journal of Hydrogen Energy, 39, 9973-9984. https://doi.org/10.1016/j.ijhydene.2014.04.147

[14] Cau, G., Cocco, D., Petrollesse, M., Kar, S.K. and Milan, C. (2014) Energy Management Strategy Based on Short-time Generation Scheduling for a Renewable Microgrid Using a Hydrogen Storage System. Energy Conversion and Management, 87, 820-831. https://doi.org/10.1016/j.enconman.2014.07.078

[15] Wang, F.C. and Chen, H.C. (2016) The Development and Optimization of Customized Hybrid Power System. International Journal of Hydrogen Energy, 41, 12261 12272. https://doi.org/10.1016/j.ijhydene.2016.05.247

[16] Kim, C.J., Hong, T., Kim, J., Kim, D. and Seo, D.Y. (2015) A Process for the Implementation of New Renewable Energy Systems in a Building by Considering Environmental and Economic Effect. Sustainability, 7, 12820-12890. https://doi.org/10.3390/su70912870

[17] Ren, H., Wu, Q., Gao, W. and Zhou, W. (2016) Optimal Operation of a Grid-Connected Hybrid PV/Fuel Cell/Battery Energy System for Residential Applications. Energy, 113, 702-712. https://doi.org/10.1016/j.energy.2016.07.091

[18] Trifkovic, M., Sheikhzadeh, M. and Nigim, K. (2014) Modeling and Control of a Renewable Hybrid Energy System with Hydrogen Storage. IEEE Transactions on Control Systems Technology, 22, 169-179. https://doi.org/10.1109/TCST.2013.2248156

[19] Mebarki, N., Rekioua, T., Mokrani, Z. and Rekioua, D. (2015) Supervisor Control for Stand-alone Photovoltaic/Hydrogen/Battery Tank System to Supply Energy to an Electric Vehicle. International Journal of Hydrogen Energy, 40, 13777-13788. https://doi.org/10.1016/j.ijhydene.2015.03.024

[20] Fathabadi, H. (2016) Novel Highly Accurate Universal Maximum Power Point Tacker for Maximum Power Extraction from Hybrid Fuel Cell/Photovoltaic/Wind Power Generation System. Energy, 116, 402-416. https://doi.org/10.1016/j.energy.2016.09.095

[21] Pellow, M.A., Emott, C.J.M., Barnhart, C.J. and Benson, S.M. (2015) Hydrogen or Batteries for Grid Storage? A Net Energy Analysis. Energy \& Environmental 
Science, 8, 1938-1952. https://doi.org/10.1039/C4EE04041D

[22] Gonzalez, E.L., Llerena, F.I., Perez, M.S., Iglesias, F.R. and Macho, J.G. (2015) Energy Evaluation of a Solar Hydrogen Storage Facility: Comparison with Other Electrical Energy Storage Technologies. International Journal of Hydrogen Energy, 40, 5518-5525. https://doi.org/10.1016/j.ijhydene.2015.01.181

[23] Kojima, T. and Tahara, K. (2001) Refinement and Transportation of Petroleum with Hydrogen from Renewable Energy. Energy Conversions and Management, 42, 1839-1851. https://doi.org/10.1016/S0196-8904(01)00045-0

[24] New Energy and Industrial Technology Development Organization (2017) The Data Base on Solar Radiation. http://app0_1.infoc.nedo.go.jp/

[25] New Energy and Industrial Technology Development Organization of Japan (2017) Guideline on Field Test Project of Photovoltaic Power Generation for Design, Construction and System. http://www.nedo.go.jp/content/100110086.pdf

[26] PanasonicCorporation (2017) Products Lineup. http://sumai/panasonic.jp/solar/lineup.html

[27] PanasonicCorporation (2017) Power Conditioner with High Conversion Efficiency. https://sumai.panasonic.jp/solar/need_power_conditioners.html

[28] Kawamoto, K., Nakatani, S., Hagihara, R. and Nakai, T. (2002) High Efficiency HIT Solar Cell. Sanyo Technical Review, 34, 111-117.

[29] Oozeki, T., Izawa, T., Otani, K., Tsuzuki, K., Koike, H. and Kurokawa, K. (2005) An Evaluation Method for PV Systems by Using Limited Data Item. IEEJ Transaction on Power Energy, 125, 1299-1307. https://doi.org/10.1541/ieejpes.125.1299

[30] Japan Meteorological Agency (2017) Climat View. http://www.data.jma.go.jp/gmd/cpd/monitor/climatview/frame.php

[31] Japan Meteorological Agency (2017) Mean Value at Each Region in the World. http://www.data.jma.go.jp/gmd/cpd/monitor/nrmlist/

[32] IHT (2017) Technical Information/Benefits of IHT's Electrolysers. http://www.iht.ch/technologie/electrolysis/industry/technical-information-benefitselectrolysers.html

[33] Kato, T. (2015) Possibility of Hydrogen Production from Renewable Energy. Journal of Japan Institute of Technology, 94, 7-18.

[34] Panasonic Corporation (2017) Specification of ENEFARM. https://panasonic.co.jp/ap/FC/about_01.html

[35] Okada, Y. (2007) Massive $\mathrm{H}_{2}$ Storage and Transportation Technology and Future Prospects. Proceedings of FC EXPO Technical Conference, 2-4 March 2007, 36-51.

[36] Nakayama, H. (2010) Safety Technology of Hydrogen Usage-The Significance and Potentiality of Hydrogen. Journal of the Japan Society of Mechanical Engineers, 113, 61-65.

[37] Iwatani Corporation (2017) Hydrogen and Iwatani. http://www.iwatani.co.jp/jpn/h2/tech/technique.html

[38] Smart Japan (2014) Realization of Dedicated Ship Conveying Liquefied Hydrogen at $-253 \mathrm{~K}$ for $6000 \mathrm{~km}$ Which Supports Hydrogen Society. http://www.itmedia.co.jp/smartjapan/articles/1402/25/news077.html

[39] Oil Federation (2017) Guideline on Revision Energy Saving Law Corresponding Cargo Owner in Oil Industry. http://www.paj.gr.jp/paj_info/data_topics/pajpg200610.pdf

[40] Collaborative Reference Database (2010) Detail of Reference Example. http://crd.ndl.go.jp/reference/modules/d3ndlcrdentry/index.php?page=ref_view\&id 
$=\underline{=000065885}$

[41] Kawasaki Heavy Industries, Ltd. (2013) First Order Entry of LNG Carrier of 182,000 $\mathrm{m}^{3}$ Type. http://www.khi.co.jp/news/detail/20130604_2.html

[42] Toyota Motor Corporation and Mizuho Information \&Research Institute, Inc. (2004) Assessment on Well-to-Wheel of Fuel for Transportation. Research Report on Global Warming Gas Emission Centered on Well-to-Tank in Japan, 1-107.

[43] Configuration Procedure (2017). http://www.jari.or.jp/portals/0/jhfc/data/report/2005/pdf/result_ref_1.pdf

[44] Example of $\mathrm{CO}_{2}$ Emission for Each Fuel (2017). https://www.env.go.jp/council/16pol-ear/y164-04/mat04.pdf

[45] Kojima, Y. and Ichikawa, T. (2011) Green Hydrogen Carrier Using Ammonia. Hydrogen Energy System, 36, 34-41.

[46] Okada, Y. and Yasui, M. (2016) Large Scale Storage and Transportation Technology of Hydrogen and Future Perspective. Chemical Engineering of Japan, 80, 398-401.

[47] Dimension and Tank Volume of Large Size Tank Truck (2017). http://usedtrucks.blog.fc2.com/blog-entry-459.html

[48] Kawasaki Heavy Industries, Ltd. (2007) Delivery of LNG Carrier “SUN ARROWS”. https://www.khi.co.jp/news/detail/c3071112-1.html

[49] Google Map (2017). https://www.google.co.jp/maps

Submit or recommend next manuscript to SCIRP and we will provide best service for you:

Accepting pre-submission inquiries through Email, Facebook, LinkedIn, Twitter, etc. A wide selection of journals (inclusive of 9 subjects, more than 200 journals)

Providing 24-hour high-quality service

User-friendly online submission system

Fair and swift peer-review system

Efficient typesetting and proofreading procedure

Display of the result of downloads and visits, as well as the number of cited articles

Maximum dissemination of your research work

Submit your manuscript at: http://papersubmission.scirp.org/

Or contact sgre@scirp.org 